\title{
Accuracy of antigen and nucleic acid amplification testing on saliva and naopharyngeal samples for detection of SARS-CoV-2 in ambulatory care
}

\section{A multicentric cohort study}

Solen Kernéis ${ }^{1,2,3 *}$, Caroline Elie ${ }^{4,5 *}$, Jacques Fourgeaud ${ }^{6,7}$, Laure Choupeaux ${ }^{4}$, Séverine Mercier Delarue $^{8}$, Marie-Laure Alby ${ }^{9}$, Pierre Quentin ${ }^{9}$, Juliette Pavie ${ }^{10,11}$, Patricia Brazille ${ }^{11,12}$, Marie Laure Néré $^{8}$, Marine Minier ${ }^{8}$, Audrey Gabassi ${ }^{8}$, Aurélien Gibaud ${ }^{8}$, Sébastien Gauthier ${ }^{13}$, Chrystel Leroy $^{14}$, Etienne Voirin-Mathieu ${ }^{14,15}$, Claire Poyart ${ }^{16,17}$, Michel Vidaud ${ }^{14,16}$, Béatrice Parfait ${ }^{13}$, Constance Delaugerre ${ }^{8,18}+$, Jean-Marc Tréluyer ${ }^{4,5} \dagger$, Jérôme Le Goff ${ }^{8,19} \dagger$

${ }^{*}$ Contributed equally

tContributed equally

\section{Affiliations of the authors}

${ }^{1}$ Université de Paris, INSERM, IAME, F-75018 Paris, France

${ }^{2}$ Equipe de Prévention du Risque Infectieux, AP-HP, Hôpital Bichat, F-75018 Paris, France

${ }^{3}$ Institut Pasteur, Epidemiology and Modelling of Antibiotic Evasion, F-75015 Paris, France

${ }^{4}$ Clinical Research Unit / Clinical Investigation Center, APHP, Necker-Enfants malades Hospital, F-

75015 Paris, France

${ }^{5}$ Université de Paris, EA 7323 Pharmacologie et thérapeutique de l'enfant et de la femme enceinte, F-

75015 Paris, France

${ }^{6}$ Virologie, AP-HP, Hôpital Necker-Enfants Malades, F-75015 Paris, France

${ }^{7}$ Université de Paris, Equipe hospitalo-universitaire 7328, Prise en charge des anomalies congénitales et de leur traitement, Institut Imagine, F-75015 Paris, France

${ }^{8}$ Virologie, AP-HP, Hôpital Saint Louis, F-75010 Paris, France

${ }^{9}$ Centre de dépistage COVISAN 1314 15, Communauté professionnelle de territoire de santé, F-

75014, Paris, France

${ }^{10}$ Immuno-Infectiologie, AP-HP, Hôtel Dieu, F-75004 Paris, France

${ }^{11}$ Centre de dépistage COVISAN, AP-HP, Hôtel-Dieu, F-75004 Paris, France

${ }^{12}$ Espace Santé Jeunes - Unité Guy Môquet, AP-HP, Hôtel-Dieu, F-75004 Paris, France

${ }^{13}$ Centre de Ressources Biologiques - site Cochin, AP-HP, Fédération des CRB/PRB d'AP-HP. Centre-

Université de Paris, Hôpital Cochin, F-75014 Paris, France

${ }^{14}$ Plateforme SeqOIA, AP-HP, F-75014 Paris, France

${ }^{15}$ Virologie, Hôpital Cochin, AP-HP, F-75014 Paris, France

${ }^{16}$ Université de Paris, INSERM, Institut Cochin 1016, F-75014 Paris, France

${ }^{17}$ Bactériologie, AP-HP Centre, Hôpital Cochin, F-75014 Paris, France

${ }^{18}$ Université de Paris, INSERM, U944, F-75010 Paris, France

${ }^{19}$ Université de Paris, INSERM, Equipe INSIGHT, U976, F-75010 Paris, France

Corresponding author

Solen Kernéis

Equipe de Prévention du Risque Infectieux

Hôpital Bichat

46 rue Henri Huchard

75018 Paris, France

Phone: + 33140.25 .60 .59

Fax: +33 140.25 .88 .11 
medRxiv preprint doi: https://doi.org/10.1101/2021.04.08.21255144; this version posted April 11, 2021. The copyright holder for this preprint (which was not certified by peer review) is the author/funder, who has granted medRxiv a license to display the preprint in perpetuity. All rights reserved. No reuse allowed without permission.

Running title: Saliva NAAT and nasopharyngeal antigen testing for SARS-CoV-2 detection

Keys words: SARS-CoV-2 ; diagnostic performances ; saliva ; antigen test ; nucleic acid amplification testing

Text word count: 3498

Abstract word count: 273

Number of figures and tables: 2 figures, 4 tables

Supplementary material: 5 tables, 4 figures

Number of references: 33 


\section{Abstract}

Background: Nasopharyngeal sampling for nucleic acid amplification testing (NAAT) is the current standard diagnostic test for of coronavirus disease 2019 (COVID-19). However, the NAAT technique is lengthy and nasopharyngeal sampling requires trained personnel. Saliva NAAT represents an interesting alternative but diagnostic performances vary widely between studies.

Objective: To assess the diagnostic accuracy of a nasopharyngeal point-of-care antigen (Ag) test and of saliva NAAT for detection of severe acute respiratory syndrome coronavirus-2 (SARS-CoV-2), as compared to nasopharyngeal NAAT.

Design: Prospective participant enrollment from 19 October through 18 December 2020.

Setting: Two community COVID-19 screening centers in Paris, France.

Participants: 1452 ambulatory children and adults referred for SARS-CoV-2 testing.

Interventions: NAAT on a saliva sample (performed with three different protocols for pre-processing, amplification and detection of SARS-(OV-2) and Ag testing on a nasopharyngeal sample.

Measurements: Performance of saliva NAAT and nasopharyngeal Ag testing.

Results: Overall, 129/1443 (9\%) participants tested positive on nasopharyngeal NAAT (102/564 [18\%] in symptomatic and $27 / 879$ [3\%] in asymptomatic participants). Sensitivity was of $94 \%$ (95\% Cl, $86 \%$ to $98 \%), 23 \%(\mathrm{Cl}, 14 \%$ to $35 \%), 94 \%(\mathrm{Cl}, 88 \%$ to $97 \%)$ and $96 \%(\mathrm{Cl}, 91 \%$ to $99 \%)$ for the nasopharyngeal Ag test and the three different protocols of saliva NAAT, respectively. Estimates of specificity were above $95 \%$ for all methods. Diagnostic accuracy was similar in symptomatic and asymptomatic individuals.

Limitations: Few children ( $n=122,8 \%)$ were included.

Conclusion: In the ambulatory setting, diagnostic accuracy of nasopharyngeal Ag testing and of saliva NAAT seems similar to that of nasopharyngeal NAAT, subject to strict compliance with specific preprocessing and amplification protocols.

Registration number: NCT04578509 
medRxiv preprint doi: https://doi.org/10.1101/2021.04.08.21255144; this version posted April 11, 2021. The copyright holder for this preprint (which was not certified by peer review) is the author/funder, who has granted medRxiv a license to display the preprint in perpetuity.

All rights reserved. No reuse allowed without permission.

Funding Sources: French Ministry of Health and the Assistance Publique-Hôpitaux de Paris Foundation. 


\section{Text}

\section{Introduction}

Prompt isolation of coronavirus disease-19 (COVID-19) cases is critical to mitigate the spread of the pandemic (1-3). This strategy implies rapid and reliable testing methods. Currently, the reference standard for diagnosis relies on detection of the severe acute respiratory syndrome coronavirus-2 (SARS-CoV-2) by nucleic acid amplification testing (NAAT) on a nasopharyngeal sample (NPS) $(4,5)$. However, nasopharyngeal sampling must be performed by trained personnel, may be technically difficult in non-cooperating patients and requires specific sampling equipment. In addition, fear of discomfort and pain with nasopharyngeal swabbing discourage patients to attend testing. With NAAT testing, swabs are centralized in specialized virology laboratories and the technic itself requires around four hours to obtain results. Altogether, these constrains restrain access to massive testing, increase time-to-result and consequently delay isolation of infectious individuals (6).

Rapid point-of-care antigen ( $\mathrm{Ag})$ testing on NPS gives results in 15 to 30 minutes. Sensitivity of $\mathrm{Ag}$ tests was estimated at $50-90 \%$ and specificity at $90-100 \%$ as compared to nasopharyngeal NAAT $(7,8)$. However, most evaluations were led on thawed SARS CoV-2-positive NPS diluted in viral transport media. Data are lacking on their point-of-care performances in real-life conditions, and in asymptomatic individuals.

Another strategy is to use alternative specimen types, such as saliva. Sample collection is simpler, painless, does not require specific skills of the personnel and opens the perspective of self-collection. Recent meta-analyses assessed diagnostic accuracies of saliva NAAT for the diagnosis of COVID-19 (9-12). All concluded that diagnostic accuracy was similar to that of nasopharyngeal swab NAAT, with pooled sensitivity estimates ranging from $83 \%$ to $88 \%$. However, the literature review revealed great variations in specimen collection, processing protocols, populations included, and of sensitivity estimates of saliva NAAT. How this heterogeneity affects performances of the diagnostic strategies remains unknown. Indeed, most protocols were imprecise on specimen collection, criteria for 
interpretation of positive results. Selection procedures of participants were also marginally described. Additionally, data are lacking on asymptomatic individuals, and on evaluations led in reallife conditions, as part of routine screening in the community.

The objectives of this large prospective multicenter study were to compare diagnostic accuracy of two alternate diagnosis strategies (nasopharyngeal Ag test and saliva NAAT) to the current reference standard (nasopharyngeal NAAT) for detection of SARS-CoV-2 in community testing centers.

\section{Methods}

Setting

The study was conducted in two community screening centers located in Paris (France) within the COVISAN program (Assistance Publique-Hôpitaux de Paris, APHP). COVISAN is the regional declination of the national framework for testing and contact tracing in the French population. Briefly, all individuals with symptoms (i.e. temperature $>37.8^{\circ} \mathrm{C}$ or chills, cough, rhinorrhea, muscle pain, loss of smell or taste, unusual persistent headaches or severe asthenia...) were invited to be tested for SARS-CoV-2 in one of the ambulatory COVISAN centers distributed across the region. Laboratory-confirmed cases were reached by phone by the COVISAN team within 24 hours to identify contacts as part of the contact tracing policy. Contacts were notified of their exposure within 24 hours of contact elicitation by phone. Symptomatic contacts were immediately referred for testing. Asymptomatic contacts were asked to self-quarantine and referred for testing 7 days after their last potential exposure. Apart from the contact tracing policy, testing was also available to all asymptomatic individuals wishing to be tested (i.e. before or after travel, participation to a gathering event).

\section{Study population and procedures}


medRxiv preprint doi: https://doi.org/10.1101/2021.04.08.21255144; this version posted April 11, 2021. The copyright holder for this preprint (which was not certified by peer review) is the author/funder, who has granted medRxiv a license to display the preprint in perpetuity. All rights reserved. No reuse allowed without permission.

All adults and children, either symptomatic or asymptomatic, referred to the two participating COVISAN centers were eligible. Eligible persons received oral and written detailed information, adapted to their age. Participants were prospectively enrolled if they were not opposed to participate to the study. We collected data on sociodemographics, past medical history, presence of symptoms, consumption of alcohol, coffee, food, smoking and teeth brushing in the hours before testing. Participants were asked to evaluate nasopharyngeal and saliva sampling on a 0- to 10-point visual analog scale (VAS) for pain ( $0=$ no pain, $10=$ worst possible pain) and simplicity/convenience $(0=$ not simple/convenient at all, $10=$ the most simple/convenient possible). For each participant, two NPS were collected by trained nurses. The first NPS was sent to the APHP high throughput platform for NAAT as part of routine care (reference method). The second NPS, collected in the second nostril, was used for rapid Ag testing immediately after sampling. The saliva sample was self-collected under supervision of the nurse, after nasopharyngeal swabbing. Saliva samples were centralized, frozen in several aliquots at $-80^{\circ} \mathrm{C}$ within 24 hours and stored for analysis. As part of routine care, results of the nasopharyngeal NAAT were communicated to participants within 24 hours via a secured email. From 4 December 2020, following approval by health authorities of Ag testing in individuals with symptoms, Ag test results were disclosed to symptomatic participants immediately after testing (study protocol amendment number 3).

\section{Virology methods}

\section{Nasopharyngeal NAAT}

NPS were centralized and processed according to the routine procedure (Appendix Table 1). Nucleic acid extraction was performed with MGIEasy Nucleic Acid Extraction Kit (MGI Tech Co, Shenzhen, China) on a MGISP-960 instrument (MGI Tech Co). SARS Cov-2 RNA amplification was done using TaqPath $^{\text {TM }}$ COVID 19 CE IVD RT PCR Kit (Thermo Fisher Scientific, Coutaboeuf, France). The technique provides results expressed as a cycle threshold ( $\mathrm{Ct}$ ) for each gene target (ORF1ab, $\mathrm{N}$ and S-genes). 


\section{$\underline{\text { Saliva NAAT }}$}

Saliva samples were tested with three NAAT procedures: "MGI-1", "MGI-2" and "Roche" (Appendix

Table 1). In the MGI-1 procedure, $150 \mu \mathrm{l}$ of saliva was mixed with $500 \mu \mathrm{l}$ of VSM02 buffer, incubated at $56^{\circ} \mathrm{C}$ for $30 \mathrm{~min}$ and then processed for extraction with the procedure used for nasopharyngeal NAAT. According to first examinations of data showing a poor sensitivity, sample testing with MGI-1 was discontinued and two alternative procedures set up (MGI-2 and Roche). All thawed saliva samples were extracted from the biobank and re-tested with the MGI-2 and Roche procedures. In the MGI-2 procedure, a $300 \mu \mathrm{l}$ aliquot of saliva was mixed with $300 \mu \mathrm{l}$ of NucliSENS ${ }^{\circledR}$ lysis buffer (Biomerieux, Marcy l'Etoile, France) and extracted with the same procedure used for nasopharyngeal NAAT. In the Roche procedure, a $150 \mu \mathrm{L}$ aliquot of saliva was mixed with $500 \mu \mathrm{L}$ of Cobas omni Lysis Reagent and tested using the Roche cobas $^{\oplus} 6800$ analyzer and Roche cobas ${ }^{\oplus}$ SARS-CoV-2 assay (Roche Diagnostics France, Myelan, France) in the virology laboratory in Saint Louis hospital, Paris, France. The technique provides results expressed as a cycle threshold $(\mathrm{Ct})$ for each gene target (ORF1ab and E-genes).

In addition, 93 other consecutive saliva samples were prospectively tested to compare fresh and frozen saliva using the MGI-2 method to detect SARS-CoV2 RNA (Appendix).

\section{Rapid antigen testing}

Nasopharyngeal Ag testing was performed with Standard Q COVID-19 Ag test (SD Biosensor ${ }^{\circledR}$, Chuncheongbuk-do, Republic of Korea). Standard Q COVID-19 Ag test is a chromatographic immunoassay for the detection of SARS-CoV-2 nucleocapsid $(\mathrm{N})$ antigen. The result was read after 15 to 30 minutes according to instructions of the manufacturer. 


\section{Statistical Analysis}

Sample size was calculated assuming that the sensitivity of the index tests was equal or superior to $60 \%$. To allow sufficient precision $( \pm 10 \%), 93$ subjects with positive nasopharyngeal NAAT were needed in each of the two subgroups (symptomatic and asymptomatic participants). To account for samples excluded for technical reasons, a sample size of 110 subjects with positive nasopharyngeal NAAT was needed in each of these subgroups. With an average positivity rate of $8 \%$ in the participating centers, 2750 subjects needed to be included. On the planned meeting of the scientific committee of the study on 16 December 2020, considering that results were urgently needed in the context of rapid degradation of the epidemiological situation in France, the scientific committee recommended to perform the analysis on participants included up to 18 December 2020.

NAAT results were considered positive if at least one gene was detected : either N, S or ORF1ab (for MGI-1 and MGI-2), and either E or ORF1ab (for Roche). Analyses of tests results were carried out blind of the result of the others and of the participant's clinical data. For each technique, Ct values reported are those for the ORF1a gene, and if not amplified, of the E-gene for Roche and of the Ngene for MG-1 and MG-2 (and of S-gene if the N-gene was not amplified).

Quantitative data were expressed as median [interquartile range], and qualitative data as counts (percentages). Diagnostic accuracy of the index tests was evaluated by calculating sensitivity and specificity. Confidence intervals were calculated by the exact binomial method. Subgroups analyses were performed according to: i) the presence of symptoms on day of testing, ii) the $\mathrm{Ct}$ value of the nasopharyngeal NAAT, expressed as low (at least one of the 3 targets with $\mathrm{Ct} \leq 28$, i.e. high viral shedding), or high (all 3 targets with $\mathrm{Ct}>28$, i.e. low viral shedding), and (iii) to the consumption of alcohol, coffee, food, and smoking or teeth brushing before sample collection. 
Sensitivity analyses were performed considering 2 alternate criteria for positivity for the reference standard: i) $\geq 2$ positive targets with nasopharyngeal NAAT, and ii) $\geq 1$ positive target with either the nasopharyngeal NAAT, saliva MGI-2 or saliva Roche. The second sensitivity analysis was performed to address the fact that the nasopharyngeal NAAT represents an imperfect reference standard, as shown by others (10).

Quantitative variables were compared with Wilcoxon's (paired test if appropriate) or Kruskal Wallis tests and qualitative variables Fisher's exact tests (Mc Nemar test if appropriate). Correlations between $\mathrm{Ct}$ values of nasopharyngeal and saliva tests were assessed by calculating the Spearman's correlation coefficient $(\rho)$. Agreement between methods for $\mathrm{Ct}$ values was assessed by calculating intraclass correlation coefficients (ICC), and on Bland-Altman plots. All statistical tests were 2-sided with a significance level of $5 \%$. The statistical analysis was performed using R software (http://cran.rproject.org/). Reporting of results followed the Standards for Reporting Diagnostic accuracy studies (STARD 2015) guideline (13).

Role of the funding sources

The funding sources had no role in the study's design, conduct and reporting.

Institutional Review Board (IRB) approval

The IRB Ile-de France III approved the study protocol prior to data collection (approval number 3840-

$\mathrm{NI})$ and all subsequent amendments.

\section{Results}

\section{Participants}


medRxiv preprint doi: https://doi.org/10.1101/2021.04.08.21255144; this version posted April 11, 2021. The copyright holder for this preprint (which was not certified by peer review) is the author/funder, who has granted medRxiv a license to display the preprint in perpetuity.

All rights reserved. No reuse allowed without permission.

Out of 1452 participants enrolled between 19 October and 18 December 2020, one participant did not provide neither nasopharyngeal nor a saliva sample and was excluded from subsequent analyses. Median age of study participants was of 36 years [26-50] and 52\% were females (Table 1 ). Indications for testing and clinical symptoms reported on day of inclusion are detailed in table 1 . One to three symptoms were observed in 409/1449 (28\%) participants.

\section{SARS CoV2 positive results}

Eight NPS (0.6\%) and 24 saliva samples (1.7\%) were not appropriately collected and were not analyzed (Appendix Figure 1). In compliant samples, technical failure led to invalid results in 12 (none for nasopharyngeal NAAT and saliva MGI-1, 8 for saliva MGI-2 and 4 for saliva Roche). Overall, 129/1443 (9\%) tested positive on nasopharyngeal NAAT: 102/564 (18\%) in symptomatic and 27/879 $(3 \%)$ in asymptomatic participants (Table 2). Detection rates were of $8 \%, 5 \%, 13 \%$ and $12 \%$ for the nasopharyngeal Ag test, saliva MGI-1, saliva MGI-2 and saliva Roche, respectively. As displayed in Figure 1, the overall median Ct value for nasopharyngeal NAAT was of 30.0 [27.6-32.1], with no difference according to the presence of symptoms and timing of testing $(p=0.21)$ (Figure 1A). The overall median Ct value for saliva NAAT MGI-2 was of 25.1 [22.3-30.3] with significantly lower Ct values in symptomatic participants tested $\leq 4$ days after symptoms onset (23.4 [21.4-26.1]) compared to those tested after 4 days (28.2 [26.1-31.0]) and those with no symptoms (27.2 [24.3-32.6], $\mathrm{p}<0.001$, Figure $1 \mathrm{~B})$.

\section{Performance of detection of SARS CoV2 infection}

Diagnostic accuracy of the nasopharyngeal $\mathrm{Ag}$ test and the three NAAT methods on saliva are presented in Table 3. Sensitivity and specificity were similar in symptomatic and asymptomatic participants. Subgroup analyses according to the $\mathrm{Ct}$ values are presented in Appendix Table 2. 
medRxiv preprint doi: https://doi.org/10.1101/2021.04.08.21255144; this version posted April 11, 2021. The copyright holder for this preprint (which was not certified by peer review) is the author/funder, who has granted medRxiv a license to display the preprint in perpetuity. All rights reserved. No reuse allowed without permission.

Consumption of alcohol, coffee, food, smoking or teeth brushing within 30 minutes before sampling had no impact on diagnostic accuracy of the three methods (data not shown).

We further analyzed correlations between Ct values on nasopharyngeal NAAT and saliva NAAT / MGI-

2 (Appendix Figure 2). On NPS and saliva samples, Ct values were moderately correlated $(\rho=0.29, \mathrm{p}$ $=0.003$ ), and higher with nasopharyngeal NAAT than saliva NAAT (median differences MIG-2 minus NPS -6.1 [-9.2;-3.7]. On saliva samples, agreement between $\mathrm{Ct}$ values with Roche and MGI-2 was moderate (Appendix Figure 3A), Ct values being almost systematically greater with MIG-2 than with Roche (median differences MGI-2 minus Roche -4.2 [-5.2;-2.6], Appendix Figure 3B).

\section{Analysis of discrepancies}

Of 1315 participants who had all three tests (nasopharyngeal NAAT and saliva NAAT with MGI-2 and Roche), 177 had a positive result with at least one technique. The Venn diagram (Appendix Figure 4) displays the number of positive results according to the technique. One hundred and five were positive with all three techniques, 66 were positive only on saliva (including 42 positive with both MGI-2 and Roche), and 5 only on NPS. As displayed on Figure 2, Ct values (MGI-2) were significantly lower in the 105 participants positive on both NPS and saliva (23.7 [21.4-26.1]) than in the 61 positive on saliva only (31.4 [26.1-35.0], $p<0.001)$. Of these 61 participants with positive saliva NAAT not detected with NPS NAAT, 18 (30\%) had Ct values $\leq 28$ on saliva.

\section{Sensitivity analyses}

The first sensitivity analysis (reference standard positive if $\geq 2$ targets positive on nasopharyngeal NAAT) found similar results (Appendix Table 3) to the main analysis. Results of the second sensitivity analysis (reference standard positive if $\geq 1$ target was positive over nasopharyngeal NAAT, saliva MGI-2 or saliva Roche) are presented in Table 4. The overall sensitivity of the nasopharyngeal Ag test decreased to $64 \%$ ( $76 \%$ in symptomatic and $40 \%$ in asymptomatic participants). The sensitivity of 
medRxiv preprint doi: https://doi.org/10.1101/2021.04.08.21255144; this version posted April 11, 2021. The copyright holder for this preprint

(which was not certified by peer review) is the author/funder, who has granted medRxiv a license to display the preprint in perpetuity.

All rights reserved. No reuse allowed without permission.

nasopharyngeal NAAT was of $65 \%$ (40\% in asymptomatic participants) compared to $93 \%$ for saliva MGI-2 and $87 \%$ for saliva Roche.

\section{Acceptability}

The median VAS score for pain was of 4 [2-6] for nasopharyngeal sampling and 0 [0-0] for saliva $(p<0.001)$. Median VAS score for simplicity/convenience was of 8 [5-10] for nasopharyngeal sampling and 9 [6-10] for saliva $(p<0.001)$. If sampling had to be repeated in the next days, 127 participants (9\%) declared that they would certainly/probably refuse another nasopharyngeal sampling, compared to $43(3 \%)$ for saliva $(p<0.001)$. Main reasons for refusal would be pain $(109 / 127,86 \%)$ for NPS or difficulties to provide the required volume for saliva $(6 / 43,14 \%)$. If participants had the choice between the two sampling methods, $882 / 1450$ (61\%) would prefer saliva, $202 / 1450$ (14\%) NPS and $366 / 1450$ (25\%) would have no preference. The large majority $(1423 / 1451,98 \%)$ estimated to be able to provide a saliva sample self-collected at home.

\section{Discussion}

In this large prospective study in two ambulatory centers, sensitivity of saliva NAAT to detect SARSCoV-2 varied depending on the pre-processing, amplification and detection procedures, ranging from 23\% (with the MGI-1 protocol) to $94-96 \%$ (with the MGI-2 and Roche protocols). Specificity was above $95 \%$ for all three methods. Diagnostic accuracy of rapid Ag testing was high, with both sensitivity and specificity above 94\%. Performances of all tests were similar in symptomatic and asymptomatic participants.

Previous studies on diagnostic accuracy of saliva for detection of SARS-CoV-2 varied greatly in specimen collection, processing protocols, and populations included (9-12). The strengths of our 
medRxiv preprint doi: https://doi.org/10.1101/2021.04.08.21255144; this version posted April 11, 2021. The copyright holder for this preprint (which was not certified by peer review) is the author/funder, who has granted medRxiv a license to display the preprint in perpetuity. All rights reserved. No reuse allowed without permission.

study are the large sample size, including a relatively high number of asymptomatic individuals, and implementation in real-life conditions, on a representative sample of the targeted population, with similar spectrum of disease prevalence and severity. All samples were performed on the exact same day in each participant, and analyzed with the same protocols, for which we provide full details on pre-processing, amplification and detection methods. To avoid any potential dependence to specific devices supply, we used dry tubes to collect saliva samples (14). We also defined criteria for positivity of the different tests and performed sensitivity analyses on these criteria to estimate the impact on diagnostic performances.

Sensitivity of saliva sampling seems similar to that of nasopharyngeal sampling for detection of SARSCoV-2. Our results further suggest that, with enhanced protocols for pre-processing and detection, saliva sampling could be even more sensitive. The majority of previous studies were lead in symptomatic individuals, and mostly in hospitalized patients. In ambulatory care, sensitivity of saliva NAAT ranges from 70.7\% (Confidence Interval: 46.1-96.1\%) to 95.7\% (93.1-97.5\%) (15-23), compared to nasopharyngeal NAAT, and the pooled sensitivity was estimated at $84.5 \%(73.0 \%-95.3 \%)$ in a recent meta-analysis (10). Most studies did not report details on the presence and dates of clinical signs, the number of genes targeted by NAAT, and only a few were able to obtain paired samples on the first day of presentation, making results difficult to compare. The reason why saliva NAAT was more sensitive than nasopharyngeal NAAT in our study remains unclear. The most straightforward explanation is that our reference standard, nasopharyngeal NAAT, was imperfect, as suggested by others (21). Another hypothesis is that viral RNA is amplified for longer periods from saliva than nasopharyngeal swabs $(19,24,25)$, but the link between detection of viral RNA in saliva and its meaning in terms of infectiousness remains to be clarified. 
medRxiv preprint doi: https://doi.org/10.1101/2021.04.08.21255144; this version posted April 11, 2021. The copyright holder for this preprint (which was not certified by peer review) is the author/funder, who has granted medRxiv a license to display the preprint in perpetuity. All rights reserved. No reuse allowed without permission.

Our study also highlights that the performances of saliva NAAT strongly depend on processing methods of samples, and illustrates that direct use of NPS methods to saliva could lead to poor performance. In our protocol, the change of lysis buffer in the MGI-2 method increased sensitivity from $23 \%$ to $95 \%$. One hypothesis is that the introduction of a significant volume of saliva into lysis buffer, compared to nasopharyngeal secretions collected by swabbing, may alter its properties and decrease efficiency of viral RNA extraction. Our results confirm that SARS-CoV2 RNA detection does not require dedicated reagents for nucleic acids preservation in saliva, and that actually, nucleic acids stabilizing may even affect detection of viral RNA (14). This illustrates that preliminary validation of analytic methods (particularly dilution and lysis buffer) is crucial to provide reliable results on saliva.

Rapid antigen testing showed very high performances in our study, even in asymptomatic individuals. The sensitivity of SARS-CoV2 antigen tests differs significantly according to populations analyzed and antigen tests used. Studies including individuals within 7 days from the onset of symptoms or from exposure to a confirmed case of COVID-19 showed a good concordance with nasopharyngeal NAAT with sensitivity estimates between $77 \%$ and $96 \%(26-28)$. In symptomatic individuals, antigen tests actually provided a better estimation of infectiousness than nasopharyngeal NAAT (29). Compared to the composite reference (positive results with either nasopharyngeal NAAT or saliva NAAT), the antigen test displayed similar performances than nasopharyngeal NAAT.

This study was limited by the relatively low number of children included. Actually, for many respiratory viruses, diagnostic accuracy of tests vary between adults and children. For SARS-CoV-2, very few studies were specifically designed in this population, but gave encouraging results (30). The ease of collecting non-invasive saliva makes it an attractive specimen for children, particularly for repeated testing. This strategy must however be specifically evaluated before large implementation, especially in young children who may have difficulties to provide the required volume of saliva (31). 
Second, nasopharyngeal NAAT is an imperfect reference method, which may contribute to overestimate diagnostic performances of alternative tests. Indeed, sensitivity of the nasopharyngeal NAAT was of only $65 \%$ (95\% Cl: $58-71)$ compared to a composite reference standard (including results of the nasopharyngeal NAAT, saliva MGI-2 and saliva Roche) in the sensitivity analysis. However, NPS is the current reference standard for sampling, and MGI-1 the technique used by the majority of screening centers in France. In this real-life evaluation, we therefore chose to use this method as the reference standard. Similarly, nasopharyngeal sampling was performed by highly trained personnel in our study, which may enhance diagnostic performances of antigen testing.

Saliva sampling is simple, painless, does not require trained personnel, and therefore offers the perspective for self-collection and iterative screening. Its main drawback is to require processing in centralized laboratories, with results available usually within 24 hours. On the other hand, rapid antigen testing provides immediate results, but still needs nasopharyngeal sampling. Considering that diagnostic accuracy seems similar for both methods, their respective advantages should be considered for implementation. Due to high acceptability, saliva NAAT should be considered in community mass screening programs or in situations where iterative screening is necessary. Several simulation studies highlighted the utility of routine iterative noninvasive saliva testing for identification of silent COVID-19 in frontline healthcare workers and prevent outbreaks in healthcare facilities $(32,33)$. By reducing sample-to-answer time, rapid antigen tests are of particular interest to allow immediate identification and prompt isolation of cases. Their point-of-care use makes them particularly useful in primary care practices or in settings where specialized laboratories are not accessible.

\section{Conclusions}


medRxiv preprint doi: https://doi.org/10.1101/2021.04.08.21255144; this version posted April 11, 2021. The copyright holder for this preprint (which was not certified by peer review) is the author/funder, who has granted medRxiv a license to display the preprint in perpetuity. All rights reserved. No reuse allowed without permission.

Saliva NAAT and nasopharyngeal Ag testing are reliable alternative strategies to identify SARS-CoV2 in both symptomatic and asymptomatic infected individuals in the ambulatory setting. Their use should be encouraged anywhere it might facilitate screening, tracing and isolation. Dedicated implementation studies are warranted to better assess the optimal respective positioning of these two strategies in the public health response, until rapid, self-collected, reliable tests are available. 


\section{Acknowledgments}

The authors thank the following members of the scientific committee for insightful comments on the study protocol and results: Bruno Lina, Anne-Geneviève Marcelin, Catherine Paugam-Burtz, Astrid Vabret, Nabil Gastli, and persons involved in data collection: Claire Kappel, Guiseppina d'Anna, Elisabeth Velin, Abdulai Jalloh, Caroline Du Song, Philippine Treluyer, Mathilde Bayle, Lucie Daveau, Marine Hellegouarch, Suzie Zhu, Pénélope Travailleur, Matthieu Kapry, Adeline Huet, Emeline Hermel, Céline Goy, Louise Lavancier.

\section{Figure captions}

Figure 1: Ct values for nasopharyngeal nucleic acid amplification testing (NAAT) and saliva NAAT (method MGI-2) according to the presence of symptoms and timing of testing after symptoms onset. 1A: nasopharyngeal $\mathrm{Ct}$ values, $1 \mathrm{~B}$ : saliva $\mathrm{Ct}$ values (MGI-2)

Figure 2: Ct values for saliva NAAT (method MGI-2) according to the result of the nasopharyngeal NAAT.

\section{Table legends}

Table 1: Characteristics of study participants. Results are presented as $\mathrm{N}(\%)$ or median [interquartile range]. 
medRxiv preprint doi: https://doi.org/10.1101/2021.04.08.21255144; this version posted April 11, 2021. The copyright holder for this preprint

(which was not certified by peer review) is the author/funder, who has granted medRxiv a license to display the preprint in perpetuity.

All rights reserved. No reuse allowed without permission.

Table 2: Number of positive samples (at least one target gene detected) according to the technical procedure: nasopharyngeal Nucleic Acid Amplification Testing (NAAT), nasopharyngeal antigen test and saliva NAAT using three different technical procedures (MGI-1, MGI-2, Roche).

Table 3: Diagnostic accuracy of the nasopharyngeal antigen test and saliva NAAT using three different technical procedures (MGI-1, MGI-2, Roche), as compared to the reference standard (nasopharyngeal NAAT, positivity defined as at least one target gene detected), according to the presence of symptoms in study participants.

Table 4: Sensitivity analysis of diagnostic accuracy of the nasopharyngeal antigen test, saliva NAAT with MGI-2 and saliva NAAT with Roche, as compared to the reference standard. The reference standard was considered positive if $\geq 1$ target was positive with either the nasopharyngeal NAAT, saliva MGI-2 or saliva Roche. 


\section{References}

1. Paltiel AD, Zheng A, Sax PE. Clinical and Economic Effects of Widespread Rapid Testing to Decrease SARS-CoV-2 Transmission. Ann Intern Med [Internet]. 2021 Mar 9 [cited 2021 Mar 16]; Available from: https://www.acpjournals.org/doi/10.7326/M21-0510

2. Bosetti P, Kiem CT, Yazdanpanah Y, Fontanet A, Lina B, Colizza V, et al. Impact of mass testing during an epidemic rebound of SARS-CoV-2: a modelling study using the example of France. Euro Surveill. 2021 Jan;26(1).

3. Du Z, Pandey A, Bai Y, Fitzpatrick MC, Chinazzi M, Piontti AP y, et al. Comparative costeffectiveness of SARS-CoV-2 testing strategies in the USA: a modelling study. The Lancet Public Health. 2021 Mar 1;6(3):e184-91.

4. Cheng MP, Papenburg J, Desjardins M, Kanjilal S, Quach C, Libman M, et al. Diagnostic Testing for Severe Acute Respiratory Syndrome-Related Coronavirus 2: A Narrative Review. Ann Intern Med. 2020 Jun 2;172(11):726-34.

5. Mustafa Hellou M, Górska A, Mazzaferri F, Cremonini E, Gentilotti E, De Nardo P, et al. Nucleic acid amplification tests on respiratory samples for the diagnosis of coronavirus infections: a systematic review and meta-analysis. Clinical Microbiology and Infection. 2021 Mar 1;27(3):341-51.

6. Ricks S, Kendall EA, Dowdy DW, Sacks JA, Schumacher SG, Arinaminpathy N. Quantifying the potential value of antigen-detection rapid diagnostic tests for COVID19: a modelling analysis. BMC Med. 2021 Mar 9;19(1):75. 
7. Peeling RW, Olliaro PL, Boeras DI, Fongwen N. Scaling up COVID-19 rapid antigen tests: promises and challenges. The Lancet Infectious Diseases [Internet]. 2021 Feb 23 [cited 2021 Mar 16];0(0). Available from:

https://www.thelancet.com/journals/laninf/article/PIIS1473-3099(21)00048-7/abstract

8. Dinnes J, Deeks JJ, Adriano A, Berhane S, Davenport C, Dittrich S, et al. Rapid, point-ofcare antigen and molecular-based tests for diagnosis of SARS-CoV-2 infection. Cochrane Database Syst Rev. 2020 Aug 26;8:CD013705.

9. Lee RA, Herigon JC, Benedetti A, Pollock NR, Denkinger CM. Performance of Saliva, Oropharyngeal Swabs, and Nasal Swabs for SARS-CoV-2 Molecular Detection: A Systematic Review and Meta-analysis. J Clin Microbiol. 2021 Jan 27;

10. Butler-Laporte G, Lawandi A, Schiller I, Yao MC, Dendukuri N, McDonald EG, et al. Comparison of Saliva and Nasopharyngeal Swab Nucleic Acid Amplification Testing for Detection of SARS-CoV-2: A Systematic Review and Meta-analysis. JAMA Intern Med. 2021 Jan 15;

11. Bastos ML, Perlman-Arrow S, Menzies D, Campbell JR. The Sensitivity and Costs of Testing for SARS-CoV-2 Infection With Saliva Versus Nasopharyngeal Swabs?: A Systematic Review and Meta-analysis. Ann Intern Med. 2021 Jan 12;

12. Fernández-González M, Agulló V, Rica A de la, Infante A, Carvajal M, García JA, et al. Performance of saliva specimens for the molecular detection of SARS-CoV-2 in the community setting: does sample collection method matter? Journal of Clinical 
Microbiology [Internet]. 2021 Jan 8 [cited 2021 Mar 16]; Available from:

https://jcm.asm.org/content/early/2021/01/08/JCM.03033-20

13. Bossuyt PM, Cohen JF, Gatsonis CA, Korevaar DA, STARD group. STARD 2015: updated reporting guidelines for all diagnostic accuracy studies. Ann Transl Med. 2016 Feb;4(4):85.

14. Griesemer SB, Van Slyke G, Ehrbar D, Strle K, Yildirim T, Centurioni DA, et al. Evaluation of specimen types and saliva stabilization solutions for SARS-CoV-2 testing. J Clin Microbiol. 2021 Mar 5;

15. Caulley L, Corsten M, Eapen L, Whelan J, Angel JB, Antonation K, et al. Salivary Detection of COVID-19. Ann Intern Med. 2021 Jan;174(1):131-3.

16. Hanson KE, Barker AP, Hillyard DR, Gilmore N, Barrett JW, Orlandi RR, et al. SelfCollected Anterior Nasal and Saliva Specimens versus Health Care Worker-Collected Nasopharyngeal Swabs for the Molecular Detection of SARS-CoV-2. J Clin Microbiol. 2020 Oct $21 ; 58(11)$

17. Kojima N, Turner F, Slepnev V, Bacelar A, Deming L, Kodeboyina S, et al. Self-Collected Oral Fluid and Nasal Swabs Demonstrate Comparable Sensitivity to Clinician Collected Nasopharyngeal Swabs for Coronavirus Disease 2019 Detection. Clinical Infectious Diseases [Internet]. 2020 Oct 19 [cited 2021 Mar 17];(ciaa1589). Available from: https://doi.org/10.1093/cid/ciaa1589 
medRxiv preprint doi: https://doi.org/10.1101/2021.04.08.21255144; this version posted April 11, 2021. The copyright holder for this preprint (which was not certified by peer review) is the author/funder, who has granted medRxiv a license to display the preprint in perpetuity.

All rights reserved. No reuse allowed without permission.

18. Landry ML, Criscuolo J, Peaper DR. Challenges in use of saliva for detection of SARS CoV-2 RNA in symptomatic outpatients. J Clin Virol. 2020 Jul 31;130:104567.

19. Miller M, Jansen M, Bisignano A, Mahoney S, Wechsberg C, Albanese N, et al. Validation of a Self-administrable, Saliva-based RT-qPCR Test Detecting SARS-CoV-2. medRxiv. 2020 Jun 9;2020.06.05.20122721.

20. Williams E, Bond K, Zhang B, Putland M, Williamson DA. Saliva as a Noninvasive Specimen for Detection of SARS-CoV-2. J Clin Microbiol. 2020 Jul 23;58(8).

21. Yokota I, Shane PY, Okada K, Unoki Y, Yang Y, Inao T, et al. Mass screening of asymptomatic persons for SARS-CoV-2 using saliva. Clinical Infectious Diseases [Internet]. 2020 Sep 25 [cited 2021 Mar 17];(ciaa1388). Available from: https://doi.org/10.1093/cid/ciaa1388

22. Pasomsub E, Watcharananan SP, Boonyawat K, Janchompoo P, Wongtabtim G, Suksuwan W, et al. Saliva sample as a non-invasive specimen for the diagnosis of coronavirus disease 2019: a cross-sectional study. Clinical Microbiology and Infection. 2021 Feb 1;27(2):285.e1-285.e4.

23. Antigen rapid tests, nasopharyngeal PCR and saliva PCR to detect SARS-CoV-2: a prospective comparative clinical trial | medRxiv [Internet]. [cited 2021 Mar 17]. Available from:

https://www.medrxiv.org/content/10.1101/2020.11.23.20237057v1.full 
medRxiv preprint doi: https://doi.org/10.1101/2021.04.08.21255144; this version posted April 11, 2021. The copyright holder for this preprint (which was not certified by peer review) is the author/funder, who has granted medRxiv a license to display the preprint in perpetuity.

All rights reserved. No reuse allowed without permission.

24. Wyllie AL, Fournier J, Casanovas-Massana A, Campbell M, Tokuyama M, Vijayakumar P, et al. Saliva or Nasopharyngeal Swab Specimens for Detection of SARS-CoV-2. N Engl J Med. 2020 Sep 24;383(13):1283-6.

25. Rao M, Rashid FA, Sabri FSAH, Jamil NN, Zain R, Hashim R, et al. Comparing Nasopharyngeal Swab and Early Morning Saliva for the Identification of Severe Acute Respiratory Syndrome Coronavirus 2 (SARS-CoV-2). Clinical Infectious Diseases [Internet]. 2020 Aug 6 [cited 2021 Mar 16];(ciaa1156). Available from: https://doi.org/10.1093/cid/ciaa1156

26. Beck ET, Paar W, Fojut L, Serwe J, Jahnke RR. Comparison of the Quidel Sofia SARS FIA Test to the Hologic Aptima SARS-CoV-2 TMA Test for Diagnosis of COVID-19 in Symptomatic Outpatients. J Clin Microbiol. 2021 Jan 21;59(2).

27. Pollock NR, Jacobs JR, Tran K, Cranston AE, Smith S, O'Kane CY, et al. Performance and Implementation Evaluation of the Abbott BinaxNOW Rapid Antigen Test in a Highthroughput Drive-through Community Testing Site in Massachusetts. J Clin Microbiol. 2021 Feb 23;

28. Merino P, Guinea J, Muñoz-Gallego I, González-Donapetry P, Galán JC, Antona N, et al. Multicenter evaluation of the Panbio ${ }^{\mathrm{TM}}$ COVID-19 rapid antigen-detection test for the diagnosis of SARS-CoV-2 infection. Clinical Microbiology and Infection [Internet]. 2021 Feb 16 [cited 2021 Mar 16]; Available from: https://www.sciencedirect.com/science/article/pii/S1198743X21000768 
29. Pekosz A, Parvu V, Li M, Andrews JC, Manabe YC, Kodsi S, et al. Antigen-Based Testing but Not Real-Time Polymerase Chain Reaction Correlates With Severe Acute Respiratory Syndrome Coronavirus 2 Viral Culture. Clin Infect Dis. 2021 Jan 20;

30. Al Suwaidi H, Senok A, Varghese R, Deesi Z, Khansaheb H, Pokasirakath S, et al. Saliva for molecular detection of SARS-CoV-2 in school-aged children. Clin Microbiol Infect. 2021 Feb 19;

31. González-Donapetry P, García-Clemente P, Bloise I, García-Sánchez C, Sánchez Castellano MÁ, Romero MP, et al. Think of the Children: Evaluation of SARS-CoV-2 Rapid Antigen Test in Pediatric Population. Pediatr Infect Dis J. 2021 Feb 17;

32. Zhang K, Shoukat A, Crystal W, Langley JM, Galvani AP, Moghadas SM. Routine saliva testing for the identification of silent coronavirus disease 2019 (COVID-19) in healthcare workers. Infect Control Hosp Epidemiol. :1-5.

33. Smith DRM, Duval A, Pouwels KB, Guillemot D, Fernandes J, Huynh B-T, et al. Optimizing COVID-19 surveillance in long-term care facilities: a modelling study. BMC Med. 2020 Dec 8;18(1):386. 
medRxiv preprint doi: https://doi.org/10.1101/2021.04.08.21255144; this version posted April 11, 2021. The copyright holder for this preprint (which was not certified by peer review) is the author/funder, who has granted medRxiv a license to display the preprint in perpetuity. All rights reserved. No reuse allowed without permission.

Table 1: Characteristics of study participants. Results are presented as $\mathrm{N}(\%)$ or median [interquartile range].

\begin{tabular}{lc}
\hline & Total \\
& N=1451 \\
\hline Age, years & $36[26-50]$ \\
Females & $755(52)$ \\
Medical conditions & \\
Hypertension & $108(7)$ \\
Diabetes mellitus & $31(2)$ \\
Hemodialysis & $5(0.3)$ \\
HIV infection & $11(0.8)$ \\
Solid organ transplant & $19(1)$ \\
Contact with a confirmed case & $564(39)$ \\
Time from last contact, days & $7[1-7]$ \\
Presence of symptoms on day of testing & $571(39)$ \\
Time from symptoms onset, days & $3[2-4]$ \\
Cough & $292(20)$ \\
Headaches & $257(18)$ \\
Rhinorrhea & $202(14)$ \\
Asthenia & $198(14)$ \\
Muscle pain & $177(12)$ \\
Fever & $163(11)$ \\
Diarrhea & $85(6)$ \\
Chills & $69(5)$ \\
Anosmia & $62(4)$ \\
Shortness of breath & $53(4)$ \\
Chest pain & $52(4)$ \\
Consumption of alcohol in the last 24 hours & $293(20)$ \\
\hline & $320(22)$ \\
Mouth washing in the last 2 hours & $271(19)$ \\
& $701(49)$ \\
& $646(45)$ \\
Constion of coffee in the last hour & $48(3)$ \\
\hline
\end{tabular}


medRxiv preprint doi: https://doi.org/10.1101/2021.04.08.21255144; this version posted April 11, 2021. The copyright holder for this preprint (which was not certified by peer review) is the author/funder, who has granted medRxiv a license to display the preprint in perpetuity. All rights reserved. No reuse allowed without permission.

Table 2: Number of positive samples (at least one target gene detected) according to the technical procedure: nasopharyngeal Nucleic Acid Amplification Testing (NAAT), nasopharyngeal antigen test and saliva NAAT using three different technical procedures (MGI-1, MGI-2, Roche).

Presence of symptoms on day of testing

Symptoms $(n=564) \quad$ No symptoms $(n=879)$

Nasopharyngeal NAAT 129/1443 (9\%)

$102 / 564$ (18\%) $27 / 879(3 \%)$

Nasopharyngeal antigen test $89 / 1115(8 \%)$

$70 / 464(15 \%)$

19/651 (3\%)

Saliva NAAT / MGI-1

$17 / 374(5 \%)$

14/174 (8\%)

$3 / 200(2 \%)$

Saliva NAAT / MGI-2

$167 / 1334(13 \%) \quad 109 / 522(21 \%)$

$58 / 812(7 \%)$

Saliva NAAT / Roche

$167 / 1391$ (12\%)

$116 / 542$ (21\%)

$51 / 849(6 \%)$ 
medRxiv preprint doi: https://doi.org/10.1101/2021.04.08.21255144; this version posted April 11, 2021. The copyright holder for this preprint (which was not certified by peer review) is the author/funder, who has granted medRxiv a license to display the preprint in perpetuity. All rights reserved. No reuse allowed without permission.

Table 3: Diagnostic accuracy of the nasopharyngeal antigen test and saliva NAAT using three different technical procedures (MGI-1, MGI-2, Roche), as compared to the reference standard (nasopharyngeal NAAT, positivity defined as at least one target gene detected), according to the presence of symptoms in study participants.

\begin{tabular}{|c|c|c|c|c|}
\hline & Total, $n$ & $\begin{array}{l}\text { Positive } \\
\text { samples, n }\end{array}$ & $\begin{array}{l}\text { Sensitivity } \\
\left(95 \% \mathrm{Cl}^{*}\right)\end{array}$ & $\begin{array}{l}\text { Specificity } \\
(95 \% \mathrm{Cl})\end{array}$ \\
\hline Nasopharyngeal antigen test & 1109 & 81 & $94 \%(86-98)$ & $99 \%(98-99)$ \\
\hline Symptoms & 459 & 64 & $95 \%(87-99)$ & $98 \%(96-99)$ \\
\hline No symptoms & 650 & 17 & $88 \%(64-99)$ & $99 \%(98-100)$ \\
\hline Saliva NAAT / MGI-1 & 372 & 69 & $23 \%(14-35)$ & $100 \%(98-100)$ \\
\hline Symptoms & 172 & 60 & $22 \%(12-34)$ & $99 \%(95-100)$ \\
\hline No symptoms & 200 & 9 & $33 \%(7-70)$ & $100 \%(98-100)$ \\
\hline Saliva NAAT / MGI-2 & 1328 & 112 & $94 \%(88-97)$ & $95 \%(94-96)$ \\
\hline Symptoms & 516 & 87 & $95 \%(89-99)$ & $94 \%(92-96)$ \\
\hline No symptoms & 812 & 25 & $88 \%(69-97)$ & $95 \%(94-97)$ \\
\hline Saliva NAAT / Roche & 1383 & 120 & $96 \%(91-99)$ & $96 \%(95-97)$ \\
\hline Symptoms & 535 & 95 & $97 \%(91-99)$ & $95 \%(92-97)$ \\
\hline No symptoms & 848 & 25 & $92 \%$ (74-99) & $97 \%(95-98)$ \\
\hline
\end{tabular}


medRxiv preprint doi: https://doi.org/10.1101/2021.04.08.21255144; this version posted April 11, 2021. The copyright holder for this preprint (which was not certified by peer review) is the author/funder, who has granted medRxiv a license to display the preprint in perpetuity.

All rights reserved. No reuse allowed without permission.

Table 4: Sensitivity analysis of diagnostic accuracy of the nasopharyngeal antigen test, saliva NAAT with MGI-2 and saliva NAAT with Roche, as compared to the reference standard. The reference standard was considered positive if $\geq 1$ target was positive with either the nasopharyngeal NAAT, saliva MGI-2 or saliva Roche.

\begin{tabular}{|c|c|c|c|c|}
\hline & Total, $\mathrm{n}$ & $\begin{array}{l}\text { Positive } \\
\text { samples, } n\end{array}$ & $\begin{array}{l}\text { Sensitivity } \\
\left(95 \% \mathrm{Cl}^{*}\right)\end{array}$ & $\begin{array}{l}\text { Specificity }{ }^{\dagger} \\
(95 \% \mathrm{Cl})\end{array}$ \\
\hline Nasopharyngeal antigen test & 1041 & 138 & $64 \%(55-72)$ & $100 \%(100-100)$ \\
\hline Symptoms & 434 & 91 & $76 \%(66-84)$ & $100 \%(99-100)$ \\
\hline No symptoms & 607 & 47 & $40 \%(26-56)$ & $100 \%(99-100)$ \\
\hline Nasopharyngeal NAAT & 1337 & 199 & $65 \%(58-71)$ & \\
\hline Symptoms & 528 & 132 & $77 \%(69-84)$ & \\
\hline No symptoms & 809 & 67 & $40 \%(28-53)$ & \\
\hline Saliva NAAT / MGI-2 & 1317 & 179 & $93 \%(89-96)$ & \\
\hline Symptoms & 511 & 115 & $95 \%(89-98)$ & \\
\hline No symptoms & 806 & 64 & $91 \%(81-96)$ & \\
\hline Saliva NAAT / Roche & 1329 & 191 & $87 \%(82-92)$ & \\
\hline Symptoms & 522 & 126 & $92 \%(86-96)$ & \\
\hline No symptoms & 807 & 65 & $78 \%(67-88)$ & \\
\hline $5 \% \mathrm{Cl}: 95 \%$ & & & & \\
\hline
\end{tabular}


medRxiv preprint doi: https://doi.org/10.1101/2021.04.08.21255144; this version posted April 11, 2021. The copyright holder for this preprint (which was not certified by peer review) is the author/funder, who has granted medRxiv a license to display the preprint in perpetuity. All rights reserved. No reuse allowed without permission.

Figure 1: Ct values for nasopharyngeal nucleic acid amplification testing (NAAT) and saliva NAAT (method MGI-2) according to the presence of symptoms and timing of testing after symptoms onset. 1A: nasopharyngeal Ct values, 1B: saliva Ct values (MGI-2)
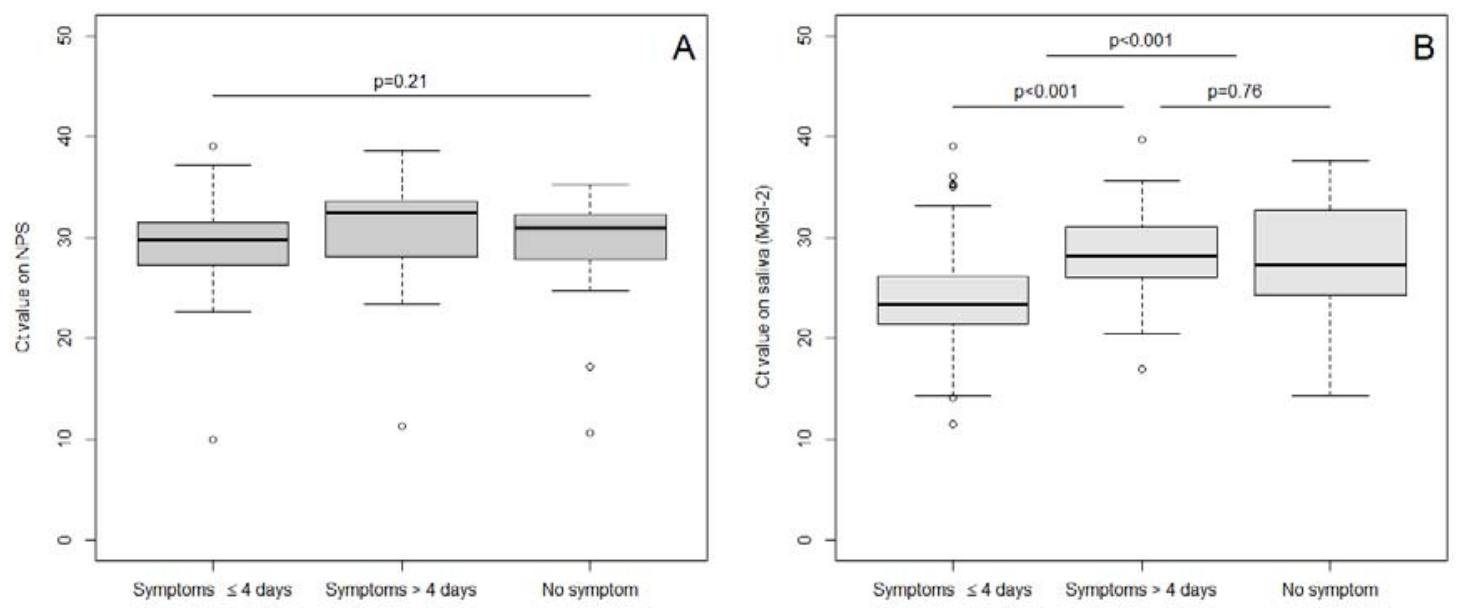

Figure 2: Ct values for saliva NAAT (method MGI-2) according to the result of the nasopharyngeal NAAT.

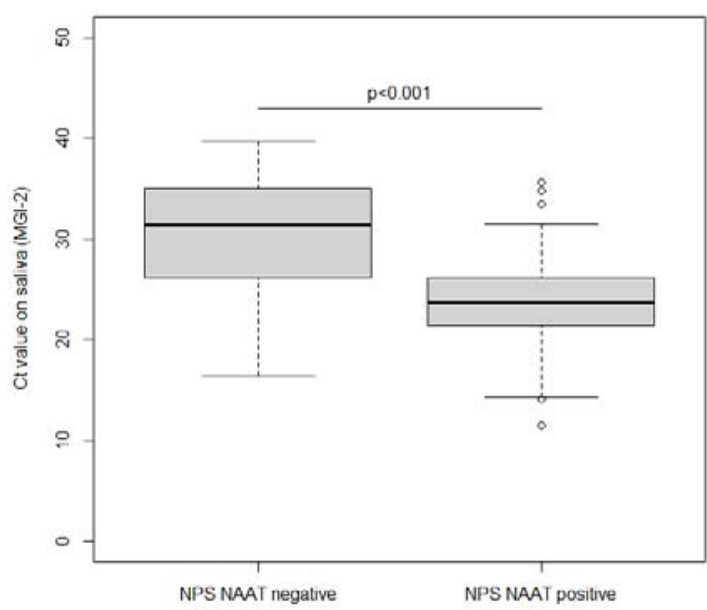

